\title{
Da Personalidade Ao Trabalho: Um Estudo Sobre O Ambiente Laborativo Dos Refugiados No Brasil E A Efetividade Das Normas
}

\author{
Gustavo Noronha de Ávila* \\ Centro Universitário de Maringá, Programa de Pós-Graduação em Direito da \\ UniCESUMAR, Maringá, Paraná, Brasil. \\ ORCID https://orcid.org/0000-0002-7239-1456
}

\section{Leda Maria Messias da Silva **}

Centro Universitário de Maringá, Programa de Pós-Graduação em Direito da UniCESUMAR, Maringá, Paraná, Brasil.

\section{ORCID https://orcid.org/0000-0003-0109-569X}

\section{Hugo Rogério Grokskreutz ***}

Centro Universitário de Maringá, Programa de Pós-Graduação em Direito da UniCESUMAR, Maringá, Paraná, Brasil.

\section{ORCID https://orcid.org/0000-0001-5837-3115}

Resumo: Os Direitos da personalidade tutelam a integridade corporal e imaterial da pessoa humana. Esses são valores gerais aplicáveis a todas as relações jurídicas, inclusive, no meio ambiente do trabalho, que é o espaço onde a pessoa exerce cotidianamente as suas atividades e seus valores personalíssimos devem ser protegidos. Por conta de perseguições decorrentes de raça, religião, nacionalidade, relações com grupos e opinião política, pessoas migram para outros Estados e são considerados como refugiados, sendo tutelados pelo sistema universal e regional americano. Para que de fato os seus direitos da personalidade sejam respeitados no meio ambiente de trabalho é necessária a efetividade de normas e, portanto, que estas promovam políticas públicas de inclusão. Assim, após o estudo ter se valido do procedimento metodológico dedutivo, bibliográfico e documental de pesquisa, com recorte em dados estatísticos, concluiu-se que as normas do Brasil se ajustam formalmente aos aludidos preceitos internacionais, e que, porém, no plano interno possuem relativa efetividade e as políticas derivadas destas ainda são insuficientes.

Palavras-chave: Refugiados. Meio ambiente do trabalho. Direitos da personalidade. Efetividade das normas. Políticas públicas inclusivas.

* Doutor em Direito com estágio pós-doutoral na PUC-RS. Professor Permanente do Programa de PósGraduação em Ciência Jurídica da UniCESUMAR. E-mail: gusnavila@gmail.com

** Doutora em Direito com estágio pós-doutoral na Universidade de Lisboa. Professora da Universidade Estadual de Maringá e do Mestrado e Doutorado em Ciências Jurídicas da UniCESUMAR. E-mail: leamd@uol.com.br

*** Coordenador e docente do Curso de Direito Centro Universitário La Salle; Mestrando em Ciências Jurídicas na UniCESUMAR. E-mail: hugorogerio.advogado@gmail.com

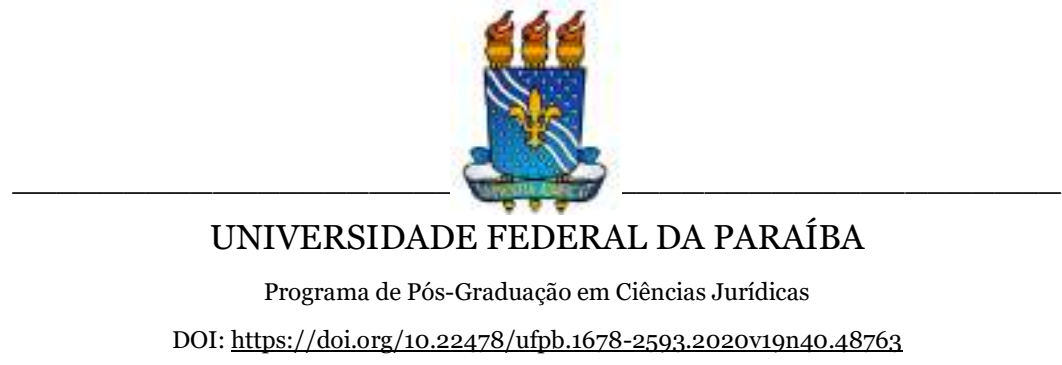





\section{Da Personalidade Ao Trabalho: Um Estudo Sobre O Ambiente Laborativo Dos Refugiados No Brasil E A Efetividade Das Normas}

Gustavo Noronha de Ávila ${ }^{1}$

Leda Maria Messias da Silva²

Hugo Rogério Grokskreutz

\section{INTRODUÇÃO}

Ao longo da história o ser humano se caracterizou pelo interesse de se deslocar de um local para outro, tais mudanças muitas vezes ocorreram por fatores de Poder que acabaram impondo o medo e o perigo para a vida digna e a integridade física daqueles que migraram.

A migração de grupos de pessoas por razões de raça, religião, nacionalidade, grupo social ou opinião política para outro território é considerado como refúgio, e geralmente ocorrem em condições precárias e de grande penúria, que retiraram o piso vital mínimo/mínimo existencial e submeteram as pessoas integrantes deste grupo de deslocados a condições indignas tanto em relação ao tratamento aos seus valores pessoais, como em aspectos trabalhistas, motivo pelo qual se levantou a seguinte indagação: o ordenamento jurídico brasileiro converge com as previsões internacionais sobre os

\footnotetext{
${ }^{1}$ Bolsista produtividade em pesquisa do ICETI.

2 Pesquisadora do Instituto Cesumar de Ciência, Tecnologia e Inovação; Bolsista produtividade em pesquisa do ICETI.
} 
Direitos da personalidade e o meio ambiente do trabalho para refugiados? É possível afirmar que há alguma efetividade destas normas? Estas normas resultam em políticas de inclusão ao meio ambiente de Trabalho?

Deste modo, o objetivo geral deste estudo repousa em averiguar se há a convergência supramencionada entre as normas do Brasil e as normas do Direito Internacional Público, especificamente em torno dos refugiados, com enfoque especial em torno da efetividade destas normas em termos de políticas públicas voltadas para a inclusão do refugiado no meio ambiente de trabalho.

E considerando que para alcançar tal objetivo mostra-se imprescindível transitar por determinados institutos jurídicos, o estudo, concomitantemente, será dotado de objetivos específicos, sendo o primeiro deles, averiguar a se a relação existente entre o trabalho, o capital e o meio do ambiente do trabalho possui conexão com os Direitos da personalidade, visto que estes, visam salvaguardar a integridade psicofísica e intelectual da pessoa.

Por sua vez, o segundo objetivo específico consistem em apontar quais as principais normas de Direito Internacional regulam a figura dos refugiados, o que leva para o terceiro objetivo específico, qual seja, analisar não apenas a Constituição da República Federativa do Brasil, mas sim, os frutos de atuação do Poder Legislativo em nível infraconstitucional, do Poder Executivo via PNDH ou banco de dados sobre a fiscalização e autuação administrativa do Ministério do Trabalho, a atuação do Poder Judiciário por meio de julgados sobre a temática dos refugiados, sem prejuízo de tecer alguns comentários sobre dados estatísticos mínimos que demonstrem certo nível efetividade.

E mais, sem a pretensão de esgotar a temática, justifica-se tal questão pelo fato de que, há diversas figuras normativas internacionais sobre refugiados, no entanto, esse arcabouço de normas pode se tornar inócuo se não houver a efetiva atuação jurídica e política dos Estados soberanos no âmbito de seus territórios. 
Da Personalidade Ao Trabalho: Um Estudo Sobre 0 Ambiente Laborativo Dos...

Nesta quadra, serão apreciadas as principais figuras do Direito internacional que versam sobre os Direitos da personalidade, meio ambiente do trabalho e os refugiados, tanto no âmbito universal da Organização das Nações Unidas (ONU), quanto do sistema regional americano, ambas as figuras pertinentes aos Direitos humanos e aos refugiados, porquanto, é indubitável a relação entre os temas.

Quanto às hipóteses é possível que haja convergência no que tange às normas nacionais e as figuras jurídicas internacionais. Do mesmo modo, o inverso igualmente não se se mostra desarrazoado, e, por esta razão, não pode ser descartado da presente pesquisa a hipótese de divergência entre tais legislações. No que toca a efetividade, a mesma é gradual e diz respeito ao fim objetivado pelo legislador, neste diapasão, exsurge a hipótese de que pode haver certo grau de efetividade, como, em concomitância, pode-se, eventualmente, alcançar a conclusão de que a norma brasileira neste ponto é completamente inócua.

Por derradeiro, registra-se que foi utilizado o método dedutivo, partindo da previsão genérica das normas internacionais para a particularidade das leis brasileiras, a pesquisa é teórica, bibliográfica e documental, constituindo-se na análise e apreciação das figuras normativas de maior destaque no ordenamento jurídico brasileiro e das normas internacionais, além de periódicos, doutrinas e jurisprudência sobre a temática, tendo ainda, um viés empírico exclusivamente em torno da efetivação destas legislações, resultando em políticas públicas.

\section{DIREITOS DA PERSONALIDADE NO MEIO AMBIENTE DO TRABALHO}

Os Direitos da personalidade podem ser compreendidos como um conjunto de Direitos que compõem valores pessoais, próprios e inerentes ao indivíduo, abarcando assim, entre outros bens jurídicos a 
intimidade, privacidade, imagem e a integridade psicofísica decorrente da dignidade humana.

Por se tratar da face privada de um princípio público fundante que é a dignidade humana, não há dúvidas de que os Direitos da personalidade compõem toda sorte de Direitos que constituem os aspectos materiais (físicos) e imateriais (morais, imagem, etc.,) do indivíduo, logo, pertencentes a todos os seres humanos (SILVA; LIMA, 2017, p. 388) e próprios de sua natureza (NERY JUNIOR; NERY, 2014, p. 320).

Entretanto, mesmo havendo as exemplificações acima, é certo que o Direito da personalidade mostra-se como uma cláusula geral que comporta todos os bens jurídicos que resguardar a pessoa em sua integralidade e cuja relevância foi prevista pelo Direito (MORAES, 2007, p. 05), por este motivo, e por ser ligado a dignidade humana, é igualmente evidente que o seu conteúdo deve ser levado em consideração em qualquer atividade hermenêutica (FIUZA, 2008, pp. 174-175), e considerada como uma condição sine qua non para quaisquer outros Direito (MEDINA; ARAÚJO, 2014, p. 54), posto que, o ser humano deve ser protegido por inteiro. (SIQUEIRA, et ali, 2018, p. 219).

Todos esses Direitos próprios do bloco de bens jurídicos da personalidade não são importantes e exercitáveis apenas no âmbito da vida privada, versa-se sobre uma cláusula geral que deve ser protegida em toda e qualquer relação jurídica, inclusive, no âmbito das relações e do ambiente do trabalho, visto que seu ventre é a dignidade humana. E na mesma toada, o meio ambiente do trabalho possui o desiderato de proteger o trabalhador em todas as suas facetas psicofísicas, afastando quaisquer cogitações sobre sua coisificação ou mera substituição (SILVA, NOVAES, 2015, p. 26), ou seja, trata-se do mesmo escopo dos Direitos da personalidade que são frutos da dignidade humana, e o trabalho por ser uma extensão da personalidade do agente deve resguardá-lo deste ambiente. (MONTENEGRO; FERRAZ; VILLATORE, 2019, p. 04) 
Portanto, se o trabalho é um prolongamento da própria personalidade do ser humano, ao tratarmos da efetividade de Lei, promovendo a dignidade da pessoa humana, no meio ambiente de trabalho, não se pode excluir aqueles que já estão em situação de vulnerabilidade, os refugiados. Nem tampouco, podemos dispensar a Lei como instrumento desta efetividade.

A palavra "trabalhar" leva em consideração o fato do indivíduo se ocupar para determinada atividade, aplicando suas energias em um ofício para chegar a um resultado (FERREIRA, 2010, p. 2.062), nas relações de trabalho tal ocupação consiste em se valer de suas forças com o propósito de produzir ou fazer algo que será comercializado ou utilizado pelo empregador que assume os riscos da atividade, mediante remuneração e subordinação. Esta relação ocorre mediante um complexo conjugado de Direitos e deveres de ambos os polos contratuais, com influência dos mais variados institutos jurídicos de ordem público-sanitárias que decorrem do denominado meio ambiente do trabalho.

A expressão "meio ambiente" (milieu ambiant) foi, ao que parece, utilizada pela primeira vez pelo naturalista francês Geoffroy de Saint-Hilaire na obra Études progressives d'um naturaliste, de 1835 , tendo sido perfilhada por Augusto Comte em seu Curso de filosofia positiva. (MILARÉ, 2015, p. 136)

Não há um conceito pacífico sobre meio ambiente, inclusive, há debate sobre o fato de ambiente já estar inserido no conceito de meio. Porém, sem adentrar nesta discussão, é possível definir o meio ambiente do trabalho (MAT) como um conjunto de condições de trabalho, leis de cunho trabalhista, influência e interações de ordem imaterial, física, química e biológica pertinente às relações trabalho, que abriga e rege a vida das pessoas envolvidas nestas relações jurídicas, e que cabe ao Poder Público fiscalizar as atividades que possam gerar risco para a vida neste meio ambiente (SÉGUIN, 2010, p. 119)".

Assim, o meio ambiente do trabalho está englobado num conceito maior de meio ambiente, havendo uma correlação entre o Direito Ambiental e o Direito do Trabalho. Ambos objetivam a melhoria da qualidade de 
vida no ambiente, vez que a agressão a este bem fundamental pode trazer consequências irreversíveis, inclusive aos direitos da personalidade do trabalhador [...] (SILVA; NOVAES, 2015, p. 25).

O denominado meio ambiente do trabalho acaba por ter o objetivo mais amplo que o Direito trabalho, pois, abarca a tutela da saúde e segurança do trabalhador no ambiente em que exerce suas atividades (FIORILLO, 2010, p. 74), motivo pelo qual, o legislador reconheceu a necessidade de conciliar o desenvolvimento econômico com os bens jurídicos ambientais (AKAOUI, 2011, p. 56), entre o microbem da ordem trabalhista em suas conectividades com o macrobem. (LORENZETTI, 2010, p. 26).

Há uma correlação entre as normas de proteção deste meio ambiente do trabalho, dos Direitos da personalidade e a dignidade humana, que obviamente se sobrepõem aos considerados como Direitos econômicos (NASCIMENTO, 2005, p. 54)". Ou seja, aqueles são intangíveis, enquanto estes não o são (DELGADO, 2010, p. 76), logo:

\begin{abstract}
Nesse sentido, não existe qualidade de vida sem qualidade ambiental, e é exatamente esse liame indissociável entre os dois conceitos que erige o direito ao meio ambiente ecologicamente equilibrado a direito humano fundamental e, mais que isso, a uma das espécies dos chamados direitos personalíssimos. (MILARÉ, 2015, p. 124)
\end{abstract}

Significa dizer que, a tutela da personalidade nas relações empregatícias ocorre tanto pelo respeito aos valores oriundos da dignidade da pessoa, quanto pela observação das formalidades legais pertinentes ao trabalho e a proteção da aludida integridade física do trabalhador, ou seja:

Para que haja proteção ao meio ambiente do Trabalho, o Direito, dessa forma, deve estabelecer condições mínimas a serem observadas pela empresa, referentes ao local de trabalho, às condições de contágio com agentes nocivos à saúde e ao perigo que a atividade pode oferecer. (FERREIRA, 2012, p. 340).

Repisa-se, não basta o respeito às normas próprias do trabalho, é imprescindível a tutela de todos os Direitos da 
personalidade em meio ao exercício do labor. Deste modo, o equilíbrio do meio ambiente é imprescindível para que seja possível se falar em proteção da integridade física, mental e moral do trabalhador (CARDOSO FILHO; TOMAZ, 2014, p. 07).

A imprescindibilidade de se resguardar em concomitância os Direitos da personalidade, assim como, o ambiente trabalhista, reside no fato de sempre haver uma contenda de interesses em nível global, de um lado, o escopo desenfreado pelo lucro mediante a banalização dos salários e das condições de trabalho, e de outro, a luta da classe trabalhadora por melhores condições e remunerações, que se refere ao capitalismo monopolista que visa uma nova ordem formada por uma maioria composta pelo proletariado e uma minoria de pessoas tidas como beneficiários (ALMEDIA-DINIZ, 1995, p. 128).

Este debate remonta a ideia de capital e de mão de obra, os proprietários do primeiro são aqueles que colhem os rendimentos da produção, enquanto que o segundo possuem apenas a força de trabalho e auferem apenas o salário pelas horas de labor, (HUBERMAN, 2017, p. 175) negociando assim a sua força de trabalho com os proprietários do capital (MARX, 1998, pp. 101-102). Porém, não é o que geralmente ocorre, o trabalhador está indubitavelmente em uma posição de inferioridade frente à grandes corporações que definem as condições de trabalho (HUNT; SHERMAN, 2010, p. 238), o que acarreta uma conjuntura social que gira em torno das necessidades de sobrevivência do homem (VILA NOVA, 2000, p. 83) e "dadas a desregulamentação do mercado de trabalho e a precarização dos empregos, a esfera profissional está na origem de uma maré crescente de sentimentos de insegurança, de desorientação, de dúvidas sobre si” (LIPOVETSKY, 2007, p. 168).

Nesta quadra, não há dúvidas da relevância do trabalho em sua relação com o capital (FERRER; ALVES, 2018, p. 25), e em que pese haver uma luta política constante entre ambas (VALENTE; FOGAÇA; SILVA, 2018, p. 03) constata-se, pelo exposto, que o homem deve ser o centro do trabalho e por mais que a economia o impulsione 
para a aquisição de novas riquezas e a geração de mais trabalho, as lutas sociais e a conquista de um Direito do Trabalho que promova a dignidade, constituem o equilíbrio entre o capital e o trabalho, para que o ser humano possa evoluir e conviver em paz. Neste aspecto, o Direito do Trabalho, tem um papel fundamental, pois é instrumento desse equilíbrio, tal qual as lutas sociais.

Antunes (2018, p. 33), neste aspecto, assevera que, mesmo na China, na qual tanto se fala em precarização, a resistência do precariado por meio de inúmeras greves tem sido fundamental para o processo de conquistas sociais, ainda que mínimas.

Quer queira, quer não, é indubitável que o conflito ocorre pela tentativa de diminuir os custos com a mão de obra, e assim obter o máximo desempenho produtivo mediante a fixação de condições indignas de trabalho. No entanto, é a resistência que faz as conquistas e avanços sociais. $\mathrm{O}$ meio ambiente de trabalho tende a melhorar quando os trabalhadores buscam por seus direitos, no entanto, por óbvio, quanto menos resistência por parte dos mesmos, mais barato se torna o trabalho de cada indivíduo e maior será o lucro dos detentores dos meios de produção, e por consequência, pior serão as condições e a ambiência do trabalho. Neste sentido:

A imposição de condições de trabalho pelo empregador, a exigência de excessivas jornadas de trabalho, a exploração das mulheres e menores, que eram a mão de obra mais barata, os acidentes com os trabalhadores no desempenho das suas atividades e a insegurança quanto ao futuro e aos momentos nos quais fisicamente não tivessem condições de trabalhar foram as constantes da nova era no meio proletariado, às quais podem-se acrescentar também os baixos salários (NASCIMENTO; NASCIMENTO, 2014, p. 43).

Diante desta conjuntura econômica, não há dúvidas de que a proteção do meio ambiente do trabalho, não só pela observância das normas trabalhistas propriamente ditas (remuneratórias, indenizatórias e de segurança), mas também, pela tutela de todos os Direitos da personalidade poderão balizar essa relação de poder existente entre a produção econômica e o trabalho prestado pelas 
pessoas que necessitam do salário para se manter, incluídos, obviamente, os refugiados.

Destaca-se que o baixo custo de produção via mão de obra barata é sem dúvida uma alternativa - ilegal - para a indústria e as empresas de prestação de serviços que permitirá que nas relações internas haja maior competitividade, e na ótica internacional igualmente admite uma expansão comercial, que, porém, é definida como dumping social, (SILVA; NOVAES, 2015, p. 26), como bem assinalou GARBACCIO, DENNY e JULIÃO:

\begin{abstract}
A globalização do final do século XX, com o barateamento da transferência de informações, possibilitou a produção distribuída em redes transnacionais, o que alterou, drasticamente, os meios de produção e as relações de trabalho. Antes as grandes empresas eram instituições organizadas e administradas, hierarquicamente, em grandes estabelecimentos produtivos com a presença física do corpo diretivo na fábrica (modelo fordista). Com o tempo, esse modelo foi se transformando na produção de acordo com a demanda, usando o mínimo de insumos, instalações e mão de obra, geridos, detalhadamente, para evitar desperdícios, e usando, para tanto, parcerias com outras empresas. Conforme haja a necessidade, as mesmas são, rapidamente, inseridas no processo produtivo (modelo toyotista). Diferente das grandes empresas fordistas, as toyotistas não se prendem ao local, são pequenos estabelecimentos produtivos conectados em rede com a empresa principal. Com essa transformação gerencial, o trabalho instável abundante das grandes produções é substituído por um grupo mínimo de trabalhadores polivalentes e, quando necessário, são contratados serviços terceirizados, temporários para suprir a demanda. Como não estão mais localizados em um único estabelecimento, nem convivem com grandes grupos de colegas, os trabalhadores do modelo toyotista experimentam o enfraquecimento de suas organizações de classe, bem como a flexibilização das relações individuais e coletivas de trabalho. (2017, pp. 1213)
\end{abstract}

Neste contexto, as unidades de trabalhos se tornam esparsas, em ambientes distintos, valendo-se do modelo intitulado de outsourcing, que se vale da terceirização das etapas da cadeia de produção, e de offshoring fábricas espalhadas por todo o planeta. (THEMUDO; NOGUEIRA, 2019, p. 19)

Em meio a essa relação de dominação do capital para com o trabalho os refugiados podem se tornar alvo fácil, pois, tudo converge 
para que estes trabalhem por valores inferiores e em piores condições sanitárias e de segurança que os nacionais, basta pensar que estes estão deslocados e não são nativos do país em que buscaram abrigo, geralmente não possuem recursos financeiros e quaisquer posses, e estão envoltos a todo tipo de necessidade material que se possa imaginar, tais como, falta de alimento, abrigo, saúde, educação, enfim, tudo que é imprescindível para uma vida humana digna. Do outro lado poderá haver um investidor ávido por mais lucro e maiores rendimentos de seu capital, que em alguns casos, não relutará em obter colaboradores informais, que auferirão um salário menor, e que muitas vezes, se submeterão a ambientes perigosos e insalubres sem questionar, lhes restando apenas com o refugo dos postos de trabalho.

Não é raro encontrar denúncias de abusos de empregadores contra imigrantes que, em busca de maiores lucros, os submetem a condições de trabalhos análogas à escravidão, como por exemplo, obrigam-lhes a trabalharem em ambientes sem ventilação, apreendem seus passaportes e os ameaçam de deportação, coagemlhes a trabalharem mais de 12 horas diariamente, pagam menos que o salário mínimo, entre outras práticas. (SILVA; LIMA, 2017, pp. 392-393)

Significa dizer que, todo o conflito entre trabalho e capital se maximiza quando a relação de trabalho envolve um refugiado, uma vez que, - como será exposto - se tratam de indivíduos que compõem um grupo vulnerável, e exatamente por este conjunto de fatores é que a interseção entre os Direitos humanos, os Direitos da personalidade, os sociais trabalhistas e o Direito dos refugiados se mostram imprescindível, porquanto, o deslocamento em massa evidenciou a correlação entre tais Direitos. (TRINDADE, 1997, p. 319)

Portanto, não há dúvidas de que os Direitos da personalidade são a face privada do mais puro interesse público que existe, qual seja, a dignidade da pessoa humana, e por se tratar de bens jurídicos que refletem a integridade psicofísica dos seres humanos que também se manifestam nas relações laborativas, é inexorável a congruência entre estes Direitos e o meio ambiente do trabalho, inclusive, naqueles em que os refugiados estão inseridos, sobretudo, por se tratar de um grupo 
Da Personalidade Ao Trabalho: Um Estudo Sobre 0 Ambiente Laborativo Dos...

vulnerável tutelado pelo arcabouço normativo internacional que será apontado.

\section{DEFINIÇÃO DE REFUGIADOS $\mathrm{E} \quad \mathrm{O}$ DIREITO INTERNACIONAL}

Ao longo da história da humanidade diversos acontecimentos podem ser considerados como precursores para que hoje uma pessoa possa ser definida como refugiada, para os adeptos de uma história evolucionista, os homo de um certo grupo expulsavam de seu território o grupo diverso forçando a migrar para outras áreas, conforme relata Harari “embora os sapiens já habitassem a África Oriental há 150 mil anos, apenas por volta de 70 mil anos atrás eles começaram a dominar o resto do planeta Terra levando as demais espécies humanas à extinção" (HARARI, 2017, p. 28). Para os cristãos Deus como entidade metafísica superior criou um casal de seres humanos prontos e acabados que foram a base da genealogia da humanidade e na relação de seus descentes houve migração, tendo Caim posteriormente ao assassinato de seu irmão Abel, sido o pioneiro dos asilados. (DEL'OLMO, 2006, p. 215)

O fato é que, independentemente da posição adotada sobre a origem da raça humana, a migração e o deslocamento em massa compõe a história civilizatória, e consequentemente, engendra a imprescindibilidade de se haver normas jurídicas para regulamentar tal episódio, logo, uma classificação jurídica também se fez necessária, motivo pelo qual, foi criada a figura do refúgio, que está relacionado com a fuga e a busca por segurança e abrigo (FERREIRA, 2010, p. 1.803) ". Juridicamente Refugiado é definido como o indivíduo que se oculta ou se resguarda em determinado local para não ser encontrada por seus inimigos (MAGALHÃES; MALTA, 1997, p. 766)”, em outros termos: 
Refugiado é todo o indivíduo que em decorrência de fundados temores de perseguição, seja relacionada à sua raça, religião, nacionalidade, associação e determinado grupo social ou opinião política, encontra-se fora de seu país de origem e que, por causa dos ditos temores, não pode ou não quer regressar ao mesmo. (GUERRA, 2012, p. 476).

Acrescenta-se a questão de severas dificuldades econômicas geralmente coletivas (MAZZUOLI, 2015, p. 828), até porque em desastres naturais, guerras e extrema pobreza é que as pessoas saem em busca de uma melhor condição de vida (SILVA; LIMA, 2016, p. 168). "Assim, são elementos essenciais do conteúdo do conceito de refúgio o fundado temor de perseguição (pelos cinco motivos citados: raça, religião, nacionalidade, grupo social ou opinião política) e a extraterritorialidade" (MAZZUOLI, 2015, p. 830), ainda deve ser acrescentada a contemporânea figura daqueles que estão passando por severas dificuldades por conta de desastres ambientes.

Ou seja, além dos casos que estão devidamente arrolados no documento internacional que regula a matéria, não se pode olvidar de que hoje existe uma nova categoria de refugiados que se manifestam em razão dos diversos problemas pertinentes aos fenômenos da natureza: o refugiado ambiental. (GUERRA, 2012, p. 478)

Por outro lado, não se pode confundir refúgio com asilo, aquele de ordem humanitária, e este, de cunho político (MAZZUOLI, 2015, p. 828) que leva em consideração crimes político ou ideológico, que são desimportantes para os refugiados (PORTELA, 2011, p. 311), em que pese o fato de ser autorizado o refúgio por opinião política, esta não se confunde com crime político que é próprio do instituto do asilo.

Outro ponto característico do asilo é que este é pleiteado por um indivíduo específico por um fator político, enquanto que o refúgio ocorre pelo deslocamento de um grupo, por isso se fala em deslocamento em massa, pois, as dificuldades e os riscos incidem como uma tempestade sobre todos em seu caminho.

Uma vez cientes da definição de refugiado é crível ressaltar que pelo princípio de non-refoulement estes não poderão ser 
Da Personalidade Ao Trabalho: Um Estudo Sobre 0 Ambiente Laborativo Dos...

devolvidos ao local de origem onde suas vidas estarão em risco (LIMA, 2017, p. 32). Este princípio estabelece a não repulsão, que é objeto tanto de normas do denominado sistema universal, quanto do sistema regional americano (há previsões em outros sistemas regionais, mas não são objeto deste trabalho).

No sistema universal uma das primeiras manifestações da sociedade internacional organizada sobre refúgio ocorreu em 1921 com a criação do "Alto Comissariado para os Refugiados Russos" pela Liga das Nações, que atuou em prol dos apátridas na época da Revolução Russa (SAADEH; EGUCHI, 1998). Como base deste sistema universal sobre refugiados, surgiu em 1933 em Genebra na Suíça a intitulada Convenção sobre o Estatuto Internacional dos Refugiados, que foi entabulada inicialmente entre Bélgica, Bulgária, Egito, França e Noruega, e teve outros adeptos ao longo do tempo (em seus art. $7^{\circ}, 8^{\circ}$ e art. 10 trata especificamente do Direito ao trabalho aos refugiados), na sequência:

Em 1938, com sede em Londres, é criado o Comitê Intergovernamental para os Refugiados (Intergovernamental Commitee on Refugees - IGCR), cuja finalidade era efetuar reassentamentos. A partir de 1943 suas atividades foram compartilhadas com um organismo criado pelos aliados, a Administração das Nações Unidas de Socorro e Reconstrução (United Nations Relief and Rehabilitation Administration - UNRRA), que visava basicamente a repatriar as vítimas da guerra dos territórios ocupados. A Administração das Nações Unidas de Socorro e Reconstrução (UNRRA) e o Comitê Intergovernamental foram substituídos, em 1947, pela Organização Internacional para os Refugiados (OIR), extinta em 1951, sendo que o Brasil foi um dos poucos países latinoamericanos que dela fez parte. (SAADEH; EGUCHI, 1998).

Em 26 de junho de 1945 na cidade de São Francisco nos Estados Unidos da América foi firmada a denominada Carta da ONU, que criou a Organização das Nações Unidas (no Brasil Decreto ${ }^{\circ}$ 19.841/1945) que trata do progresso social e prevê níveis mais alto de trabalho efetivo (art. 1.3 e 55, 'a'). Em 1948 a ONU por meio da Resolução n ${ }^{\circ}$ 217-A-III de sua Assembleia Geral instituiu a Declaração Universal de Direitos Humanos (DUDH) que prevê o asilo, o Direito 
de deixar e de regressar a seu país, e o Direito ao trabalho (art. 13.2, art. 14.1 e art. 23).

Posteriormente vieram às famosas quatro Convenções de Genebra de 1949 para a proteção das pessoas em caso de conflito armado (LEITE, 2011, p. 35) e uma destas figuras que aborda o tema refugiado é a IV Convenção de Genebra de 1950 "para proteção das pessoas civis em tempos de guerra", entre eles os refugiados (art. $44 \mathrm{e}$ art. 70). Ainda em 1950 a ONU por sua Assembleia Geral instituiu o Estatuto do Escritório do Alto Comissariado das Nações Unidas para os Refugiados (ACNUR) por meio da Resolução 428-A-V, que promove políticas junto aos Estados e considera o dia 20 de junho como o "dia mundial do refugiado".

Em 1951 foi realizada a Conferência das Nações Unidas de Plenipotenciários sobre o Estatuto dos Refugiados e Apátridas na cidade de Genebra na Suíça e resultou na denominada Convenção Relativa ao Estatuto do Refugiado (no Brasil Decreto ${ }^{\circ}{ }^{50.215} / 1951$ ), que traz regras específicas sobre a proteção e os procedimentos em torno do refúgio a igualdade de condições de trabalhos (no art. 17.1), neste mesmo ano foi criada a Organização Internacional para as Migrações (OIM).

Em 1966 na cidade de Nova Iorque foi criado o Pacto Internacional de Direitos Civis e Políticos (art. $8^{\circ}$ ) (no Brasil Decreto $\mathrm{n}^{\circ}$ 592/1992) e o Pacto Internacional de Direitos Econômicos, Sociais e Culturais (art. $6^{\circ}$ a 10) (no Brasil Decreto ${ }^{\circ}$ 591/1992) ambos garantem o Direito ao trabalho juridicamente regulamentado a todos, logo, suas previsões igualmente se aplicam em prol dos refugiados.

Visando corroborar com a Convenção Relativa ao Estatuto do Refugiado de 1951, foi firmado o Protocolo sobre o Estatuto dos Refugiados de 31 de janeiro de 1967 na cidade de Nova Iorque (no Brasil Decreto $\left.n^{\circ} 70.946 / 1972\right)$, que afastou os limites geográficos europeus expandindo os efeitos da Convenção para todo o planeta.

De 22 de abril a 13 de maio de 1968 a ONU realizou a primeira Conferência Internacional de Direitos Humanos - Proclamação de Teerã - que em seu art. 13 prevê a indivisibilidade de todos os Direitos 
humanos, no mesmo sentido, a Declaração e Programa de Ação de Viena decorre da Conferência Mundial sobre Direitos Humanos de 14 a 25 de junho do ano de 1993 traz semelhante disposição em seu art. $5^{\circ}$ (ambas apontam o sentido interpretativo da DUDH). Na mesma toada em 2016 nos Estados Unidos da América a ONU firmou a Declaração de Nova Iorque para refugiados e imigrantes, e em dezembro de 2018 foi criado o Pacto Global para a migração em Marraquexe no Marrocos.

Por fim, a Organização Internacional do Trabalho (OIT) além de possuir as Convenções no 19/1925, n 97/1939 e n ${ }^{\circ}$ 143/1975 sobre o trabalho do migrante, inovou por meio da Recomendação $\mathrm{n}^{\circ}$ 205/2017 que deu especial atenção aos refugiados, e entre outros pontos impôs aos Estados a obrigação de atuarem em conjunto para fomentar o acesso ao mercado de trabalho a este grupo vulnerável (item 28).

De outro lado, há o Sistema Regional Americano de Direitos Humanos, que compreende diversos Tratados e seus respectivos protocolos ladeados por declarações, cuja essência de suas políticas também o esforço para proteger os refugiados (BARRICHELLO; ARAÚJO, 2014, p. 74). No Rio de Janeiro no Brasil em 1947 foi criada a Carta Internacional Americana de Garantias Sociais do Trabalhador em seu art. $2^{\circ}$, alínea 'e' estipula que os direitos dos trabalhadores beneficiam a todos os habitantes do território, nacionais ou estrangeiros, o que abarca também os refugiados.

Um dos documentos pioneiros na construção deste Sistema Regional Americano é a denominada Carta da Organização dos Estados Americanos (Carta da OEA) de 1948 (no Brasil Decreto n ${ }^{\circ}$ 30.544/1952) que foi expressa no sentido de trazer previsão sobre os Direitos da personalidade (art. $3^{\circ}$, alínea 'l' e art. 45, alínea 'a') e do trabalho (art. 34, alínea 'a' e art. 45, alínea 'b'), em complemento, foi criado o chamado Protocolo de Washington de 1992 (no Brasil Decreto $\mathrm{n}^{\circ}$ 2.760/1998). Na mesma senda a denominada Declaração Americana dos Direitos e Deveres do Homem de 1948, também 
estipulou Direitos da personalidade a todos e sem prejuízo dos refugiados (art. $1^{\circ}$, art. $5^{\circ}$, art. $9^{\circ}$ e art. 10) e o resguardo do trabalho (art. 14, art. 15 e art. 16).

Depois destas duas figuras se iniciou construção graduação de ferramentas de tutela de Direitos humanos neste sistema regional (MAZZUOLI, 2011, p. 20), e nesta toada surgiu a Convenção Americana de Direitos Humanos (Pacto de San José da Costa Rica ou CADH) de 1969 (no Brasil Decreto $n^{\circ}$ 678/1992), que sem dúvidas é um dos principais instrumentos normativos internacionais deste sistema regional e que, salvaguarda a personalidade humana (art. $3^{\circ}$ ) e prevê a importância do trabalho (art. $6^{\circ}$ ). Para complementar o aspecto social, foi entabulado em 1988 o seu Protocolo Adicional em matéria de Direitos Econômicos, sociais e culturais (Protocolo de San Salvador) (no Brasil Decreto $\mathrm{n}^{\circ} 3 \cdot 321 / 1999$ ) que também prevê a personalidade humana (art. 13.2) e garante o Direito ao trabalho (art. $6^{\circ}$ ao art. $9^{\circ}$ ), e em seu art. $3^{\circ}$ rechaça qualquer forma de condicionamento da personalidade jurídica. (GOMES; MAZZUOLI, 2013, p. 38)

Em relação mencionado art. $6^{\circ}$, os juristas ainda consignaram que o desiderato é evitar o denominado neoescravismo que ocorre pela falta de condições dignas de trabalho, notadamente, aos imigrantes, que acreditam em promessas de vantagens, mas que em verdade estão colocando sua vida em risco (GOMES; MAZZUOLI, 2013, p. 58). E neste ponto é que surge a possibilidade de responsabilidade internacional por descumprimento de quaisquer destas figuras normativas.

A Convenção Americana de Direitos Humanos trouxe em seu bojo a instituição da Corte Interamericana de Direitos Humanos competente para punir nos parâmetros da Convenção os Estados inadimplentes (GROKSKREUTZ, 2013, p. 136)". E especificamente no que tange aos refugiados já houve apreciação empírica no caso $\mathrm{n}^{\circ}$. 12.474 - Familia Pacheco Tineo vs. Estado Plurinacional de Bolivia (COMISIÓN INTERAMERICANA DE DERECHOS HUMANOS, 2015, p. 212) nos seguintes moldes: 
[...] 197. La Corte reitera que el derecho de buscar y recibir asilo establecido en el artículo 22.7 de la Convención Americana no asegura que deba reconocerse el estatuto de refugiado a la persona solicitante, pero sí que su solicitud sea tramitada con las debidas garantias [...]. 198. En este caso, en relación con la denegatoria de la solicitud de asilo, el Estado violó los derechos a las garantías judiciales, a buscar y recibir asilo, el principio de no devolución, y el derecho a la protección judicial, reconocidos en los artículos 8, 22.7, 22.8 y 25 de la Convención Americana [...] - El Estado Plurinacional de Bolivia es responsable por la violación del derecho a buscar y recibir asilo, del principio de no devolución (contenidos en el derecho de circulación y residencia) y de los derechos a las garantías judiciales y a la protección judicial, reconocidos en los artículos 22.7, 22.8, 8 y 25 de la Convención Americana, en relación con el artículo 1.1 del mismo instrumento, en perjuicio del señor Rumaldo Juan Pacheco Osco, de la señora Fredesvinda Tineo Godos, y de Frida Edith, Juana Guadalupe y Juan Ricardo, los tres de apellido Pacheco Tineo, en los términos de los párrafos 126 a 199 de la presente Sentencia. (CADH, 2015)

Ainda no plano de evolução normativo-internacional a Declaração de Cartagena proveniente do Colóquio sobre Proteção Internacional dos Refugiados na América Central, México e Panamá: Problemas Jurídicos e Humanitários, realizado na cidade de Cartagena na Colômbia em 1984, estipula no item II alínea 'h' o desiderato de "fortalecer os programas de proteção e assistência aos refugiados, sobretudo nos aspectos de saúde, educação, trabalho e segurança”. Em 1989 foi realizada a Conferência Internacional sobre Refugiados Centro-americanos (CIREFCA) que resultou nos Princípios e critérios para a proteção e assistência aos refugiados, repatriados e deslocados, em outras palavras:

Al respecto, la Corte Interamericana ha sostenido que en atención al desarrollo progresivo del derecho internacional, las obligaciones derivadas del derecho a buscar y recibir asilo resultan operativas respecto de aquellas personas que reúnan los componentes de la definición ampliada de la Declaración de Cartagena sobre Refugiados de 1984, la cual responde no sólo a las dinámicas de desplazamiento forzado que la originaron, sino que también satisface los desafios de protección que derivan de otros patrones de desplazamiento que suceden en la actualidad. Este criterio refleja una tendencia a consolidar en la región una definición más incluyente que debe ser tomada en cuenta por los Estados a fin de 
otorgar la protección como refugiado a personas cuya necesidad de protección internacional es evidente. (COMISIÓN INTERAMERICANA DE DERECHOS HUMANOS, 2015, pp. 68-69)

E mais, em 1994 foi realizado o Colóquio Internacional em Comemoração do Décimo Aniversário da Declaração de Cartagena sobre Refugiados, denominada de Declaração de San José sobre Refugiados e Pessoas Deslocadas; em 2004 em comemoração ao vigésimo aniversário da já citada Declaração de Cartagena foi realizada a Declaração e Plano de Ação do México para Fortalecer a Proteção Internacional dos Refugiados na América Latina; e em comemoração ao trigésimo aniversário da Declaração de Cartagena foi realizada a Declaração do Brasil de 2014, tida como "um Marco de Cooperação e Solidariedade Regional para Fortalecer a Proteção Internacional das Pessoas Refugiadas, Deslocadas e Apátridas na América Latina e no Caribe" (Cartagena +30$)$.

Diante das definições e previsões supracitadas, é possível denotar que o refugiado se desloca para outro local visando segurança e uma nova vida, já que a anterior foi prejudicada por conta de perseguições (ANDRADE; RAMINA, 2018, p. 29). Estes seres humanos buscam um ambiente livre de qualquer espécie de perseguição, ao que tudo indica, a maciça maioria de refugiados busca um porto seguro, para que possam ter uma vida comum como qualquer outra pessoa, com um labor, com conquistas econômicas, sociais, enfim, com toda sorte de Direitos e deveres que possam ser exercidos sem o receio de que em certo momento sua dignidade será mitigada ou extirpada por conta de um posicionamento diverso do Poder dominante do seu Estado de origem.

Logo, é inevitável que os migrantes refugiados terão relações jurídicas de cunho trabalhista. Nesse sentido, igualmente deverão ser tutelados pelas normas jurídicas tanto nacionais, quanto internacionais incidentes sobre o Estado que o recepcionou. Assim, pode-se afirmar que estes se ajustam ao conceito de grupo vulnerável em sentido estrito, temporário e merecedores de discriminação 
positiva mediante a fixação de políticas públicas em seu favor (SIQUEIRA, 2013, p. 185) e que possam inverter a discriminação negativa, fazendo com que a igualdade material não seja mero argumento retórico. (RIBEIRO, 2011, p. 183)

Para que exista igualdade material, é imperativo que haja normas jurídicas e políticas públicas eficientes (DAVIES, 2010, p. 32) para a inserção dos vulneráveis no manto de proteção do Estado como forma de garantir-lhes o desenvolvimento de suas personalidades e dignidade (SIQUEIRA; MARTA, 2009, p. 143). E por estarem em uma situação de vulnerabilidade, os refugiados necessitam de um tratamento desigual para que possam ser igualados aos que não estão submetidas as mesmas condições, aplicando-se desta forma a denominada igualdade material, que por sua vez, será concretizado por meio de políticas públicas específicas, o que implica em um tratamento jurídico igualmente especial, e neste ponto é que há intersecção entre os Direitos da personalidade, o meio ambiente do trabalho e as normas sobre refugiados.

\section{ANÁLISE DAS NORMAS DO ESTADO BRASILEIRO}

De proêmio a Constituição da República Federativa do Brasil trouxe como elemento fundamental do Estado a dignidade da pessoa humana, e os valores sociais do trabalho e livre iniciativa (art. $1^{\circ}$, incisos III e IV), e mesmo não tendo mencionado expressamente a figura do refúgio ressaltou a prevalência dos Direitos humanos, a cooperação entre os povos e o asilo como para a progressão da humanidade como princípios das relações internacionais (art. $4^{\circ}$, incisos II, IX e X).

Igualmente trouxe um conjunto de Direitos fundamentais com diversas previsões de Direitos da personalidade aplicáveis tanto aos brasileiros, quanto aos estrangeiros em território nacional (art. $5^{\circ}$, caput, incisos I, V, X, XI, XII entre outras figuras), alguns definidos 
como sociais (art. $6^{\circ}$ ) e indicou vários outros de ordem trabalhista (art. $7^{\circ}$ ). No mesmo diapasão, condicionou a economia aos ditames da justiça social e na garantia da existência digna, fixou a defesa do meio ambiente, a redução das desigualdades sociais e a busca do pleno emprego como princípios da atividade econômica (art. 170, caput e incisos VI, VII e VIII), além de trazer expressamente o meio ambiente equilibrado, inclusive, do trabalho, como Direito de todos (art. 200, inciso VIII e 225).

Nesta senda, para que se possa garantir a dignidade e, portanto, os direitos da personalidade no meio ambiente de trabalho, se faz essencial que os direitos sociais previstos em nossa Carta Magna, sejam plenamente assegurados, como forma de garantir igualdade e solidariedade com a participação de todos (CECATO; OLIVEIRA, 2016, p. 19). Porquanto, a proposta dos direitos sociais vai além de políticas para que os mais necessitados possam prover a sua existência ou políticas de transferência de renda, mas sim, uma proposta de inclusão ou, no contexto da pesquisa que ora se apresenta neste artigo, inclusão de seres humanos, quer seja um nacional ou um refugiado.

Com arrimo nessas previsões da Carta Magna brasileira é possível asseverar que no plano teórico constitucional as normas tupiniquins convergem com as normas internacionais aportadas no início deste trabalho em relação aos Direitos da personalidade, meio ambiente e refugiados, e mais, da análise do art. $5^{\circ}, \S 1^{\circ}, \S 2^{\circ}$ e $\S 3^{\circ}$ é possível denotar que os Direitos humanos consagrados em prol dos refugiados possuem aplicabilidade imediata no âmbito interno deste Estado, são materialmente constitucionais, e podem no futuro serem formalmente inseridas no conceito de emenda constitucional.

Em nível infraconstitucional o Brasil possui um conceito de meio ambiente no art. $3^{\circ}$, inciso I, da Lei da Política Nacional do Meio Ambiente (Lei ${ }^{\circ}$ 6.938/1981) que considera como "meio ambiente, o conjunto de condições, leis, influências e interações de ordem física, química e biológica, que permite, abriga e rege a vida em todas as suas formas". 
Da Personalidade Ao Trabalho: Um Estudo Sobre 0 Ambiente Laborativo Dos...

Em relação aos Direitos da personalidade, o Código Civil (CC) do art. 11 ao art. 21 inovou no sistema normativo interno ao tratar pela primeira vez sobre estes Direitos, e em que pese haver debates jurídicos sobre a extensão e limites previstos nestes dispositivos, é certo que o Brasil avançou em relação a proteção dos aspectos privados da pessoa humana, e tais normas se aplicam aos refugiados já que não há previsão em contrário.

Ainda em relação aos Direitos da Personalidade o Decreto-Lei $\mathrm{n}^{\circ}$ 5.452/1943 (Consolidação das Leis do Trabalho - CLT) após as alterações promovidas pela Lei $n^{0} 13.467 / 2017$ e a Medida Provisória $n^{\circ} 808 / 2017$ (vigência encerrada) passou a prevê-los expressamente em seu art. 223-C de maneira tabelada, desigual e tida até mesmo como inconstitucional (estes pontos não serão aprofundados para não fugir da temática), ainda reconhece entre outros a existência do ambiente de trabalho (art. 456-A), a proteção da integridade do trabalhador (art. 154-A e seguintes) e o trabalho insalubre e perigoso (art. 189).

No que tange especificamente aos refugiados há o intitulado Estatuto do Refugiado (Lei $n^{\circ}$ 9.474/1997) que em seu art. $1^{\circ}$ os define como sendo todos os indivíduos que "devido a fundados temores de perseguição por motivos de raça, religião, nacionalidade, grupo social ou opiniões políticas encontre-se fora de seu país de nacionalidade e não possa ou não queira acolher-se à proteção de tal país”, além dos apátridas e os que "devido a grave e generalizada violação de direitos humanos, é obrigado a deixar seu país de nacionalidade para buscar refúgio em outro país”. Segundo o seu art. 11 o órgão de deliberação coletiva no âmbito do Ministério da Justiça com competência para os processos administrativos pleiteando refúgio é o "Comitê Nacional para os Refugiados” (CONARE), cuja decisão, poderá ser objeto de recurso para aludido órgão do Ministério da Justiça (art. 17 e seguintes e art. 29). A própria criação do CONARE, pode ser considerada um avanço e a Lei de Migração, citada a seguir, que prevê a inclusão laboral por meio de políticas públicas. 
A revogada Lei $\mathrm{n}^{\circ}$ 6.815/1980 (estatuto do estrangeiro) autorizava a concessão de passaporte aos refugiados (art. 55, inciso I, alínea 'a'), atualmente há a Lei da Migração (Lei n 13.445/2017) que em seu art. $2^{\circ}$ não afasta a incidência de outras normas nacionais ou internacionais, enquanto que o art. $3^{\circ}$ traz os princípios e diretrizes para a política migratória especialmente os Direitos humanos, igualdade de tratamento e oportunidade e a inclusão laboral por meio de políticas públicas (incisos I, IX e X), enquanto que em seu art. $5^{\circ}$ traz os Direitos sociais, associação sindical, proteção das Leis trabalhistas e o respeito as normas constitucionais e convencionais (I, VII, XI e $\S 1^{\circ}$ ).

E mais, o Brasil possui legislação pertinente a grupos migratórios vulneráveis por conta de crise humanitária, versa-se sobre a Lei $\mathrm{n}^{\circ} 13.684 / 2018$ que em seu art. $5^{\circ}$ estabelece a proteção social, formação e qualificação profissional e os Direitos humanos. Da redação da Lei Maior pátria, da Lei da Política Nacional do Meio Ambiente, do CC e da CLT, e das leis extravagantes e específicas em torno dos refugiados resta evidenciado que o Estado brasileiro tutela legalmente o meio ambiente, que abarca as relações de trabalho, tutela os Direitos da personalidade de forma cogente, e garante todos estes Direitos aos refugiados, nesta quadra, é possível observar que a parcela do Estado representada pelo Poder Legislativo atende aos ditames internacionais supracitados.

De outro lado, o Poder Executivo Federal possui políticas públicas em prol de garantir a eficácia de todas as normas protetivas do meio ambiente do trabalho e dos Direitos da personalidade em prol dos refugiados. Este formalizou o I Programa Nacional de Direitos Humanos (PNDH-I) no corpo do Decreto ${ }^{\circ} 1.904 / 1996$, que fixou políticas públicas a serem adotadas pelo Estado brasileiro daquele momento em diante, em sua introdução constou que os Direitos humanos são os Direitos fundamentais de todos, inclusive dos refugiados, e fixou as políticas públicas de $\mathrm{n}^{\circ}$ 64, 165, 166 e 167 em síntese tratando da proteção dos estrangeiros e a obrigação do Estado de criar um estatuto para os refugiados. 
Da Personalidade Ao Trabalho: Um Estudo Sobre 0 Ambiente Laborativo Dos...

O PNDH II lançado pelo Decreto $\mathrm{n}^{\circ} 4.229 / 2002$ revogou o programa anterior e trouxe em seu bojo 05 (cinco) propostas de políticas públicas tombados sob o $\mathrm{n}^{\circ} 250,251,252,253$ e 254 que em sinopse trata do apoio ao CONARE, implemento da Convenção de 1951 e seu protocolo, apoio aos estudos, pesquisas e a capacitação dos refugiados. Por sua vez, o PNDH III fruto do Decreto $n^{0}$ 7.037/2009 nada disse sobre os refugiados, com exceção do seu eixo $\mathrm{V}$ sobre educação que menciona a troca de experiências entre as crianças migrantes, e pior, revogou completamente o Programa anterior, demonstrando assim um significativo retrocesso em relação a temática dos refugiados ao menos no aspecto formal.

A Lei de Migração é regulamentada pelo Decreto $\mathrm{n}^{\circ}$ 9.199/2017 que estabeleceu procedimentos específicos para o ingresso de refugiados e sua documentação em solo nacional. O Conselho Nacional de Migração (CNIg) e o Comitê Nacional para Refugiados (CONARE) expediram a Portaria Conjunta $\mathrm{n}^{\circ}$ 01/2018 que autoriza a residência para questões laborais aos refugiados. Da mesma forma o Decreto $\mathrm{n}^{\circ}$ 9.285/2018 reconheceu a situação de vulnerabilidade oriundo do fluxo migratório provocado pela crise humanitária na Venezuela.

A chamada reforma administrativa, alocou a Política Nacional sobre Refugiados na pasta da Secretaria Nacional de Justiça (SNJ) ligada ao Ministério da Justiça (MJ) e a estruturação, implementação e monitoramento desta política ao Departamento de Migração, conforme art. 13, inciso III, alínea 'b' e art. 15, incisos I, II, VIII e IX do Decreto $\mathrm{n}^{\circ}$ 9.662/2019. Anteriormente a Lei $\mathrm{n}^{\circ} 13.502 / 2017$ estipulava como área do Ministério do Trabalho a política de migração laboral (art. 55, inciso VII), todavia, tal legislação foi revogada pela Medida Provisória n ${ }^{\circ}$ 870/2019 que transferiu a temática para a pasta do Ministério da Justiça e Segurança Pública (art. 37, XII), igualmente, de acordo com o Decreto ${ }^{\circ}$ 9.673/2019 haverá um Assessor para Assuntos sobre Refugiados junto à Secretaria Nacional de Proteção Global (anexo II) definido como órgão específico singular, que por sua 
vez, compete entre outros pontos coordenar e monitorar a implementação do PNDH (art. 23, inciso II), que como já afirmado, não trouxe previsão sobre políticas públicas para refugiados.

Ainda sobre o Brasil, foi realizada a I Conferência Nacional sobre Migração e Refúgio (Comigran) em 2014, que entre os eixos centrais consta a "inserção social, econômica e produtiva" (LIMA, 2017, p. 60). Em que pese os dados supramencionados, o Brasil de maneira informal se dissociou do aludido Pacto Global para Migração (UNISINOS, 2019), fato este que pode ser considerado como um retrocesso - ao menos formal - em relação proteção dos refugiados que buscarem abrigo neste Estado.

No tocante as relações laborativas, o Poder Executivo Federal por meio do Ministério do Trabalho possui Normas Regulamentadoras sobre segurança e saúde dos trabalhadores, que se aplicam a todos os trabalhadores - não exclui os refugiados - e no rol destas figuras há a NR $n^{\circ}$ o9 e a NR $n^{\circ} 18$ ambas tratando do meio ambiente do trabalho.

Em relação ao aspecto educacional, o Ministério da Educação como órgão do Poder Executivo Federal por meio da Resolução $\mathrm{n}^{\mathrm{o}}$ $3 / 2016$ em seu art. $8^{\circ}, \S 3^{\circ}$ permite que os refugiados que não estejam munidos da documentação requerida possam participar dos processos de revalidação de títulos acadêmicos estrangeiros, nos moldes do art. 48, §2 ${ }^{\circ}$ da Lei 9.394/1996 (LDB). Neste mesmo ano de 2016, o governo federal, em parceria com o MEC, por meio da Resolução 03/2016, lançou a plataforma Carolina Bori, que prometeu agilizar o processo de reconhecimento de diplomas, mas tal processo é burocrático e pode demandar documentos que o refugiado não possui.

Além destes pontos, de política pública nacional, o Ministério da Justiça (MJ) via Secretaria Nacional de Justiça (SNJ) lançou os editais de chamamento público $\mathrm{n}^{\circ} 01 / 2018$ (item 2.2) e 02/2018 (item 2.1) com recurso limitados visando respectivamente a inclusão social, laboral e produtiva e parceria com entidades sem fins lucrativos visando reassentar núcleos familiares de refugiados, inclusive, com a capacitação e inserção no mercado de trabalho. 
Da Personalidade Ao Trabalho: Um Estudo Sobre 0 Ambiente Laborativo Dos...

Em relação ao Poder Judiciário e a título de exemplificação do reconhecimento dos Direitos dos refugiados, o Supremo Tribunal Federal (STF) ao julgar os pleitos de extradição tombados sob o $\mathrm{n}^{\circ} 1170$ e $\mathrm{n}^{\circ} 1008$ obstou a devolução de refugiados, enquanto que, o Superior Tribunal de Justiça (STJ) reconheceu o Registro Nacional de Estrangeiro como válido para todos os fins no REsp 1475580/RJ, o Direito ao contraditório antes da expulsão do refugiado no $\mathrm{HC}$ 333.902/DF, também se reconheceu o cabimento de ação civil pública visando benefício assistencial a refugiados no REsp 1487032/SP; já o Superior Tribunal do Trabalho (TST) indiretamente considerou a condição de refugiado como um fator de estresse no AIRR $\mathrm{n}^{\circ} 5^{8-}$ 91.2011.5.04.0030, em sinopse, o Poder Judiciário não é dissociado das dificuldade que afetam os refugiados.

Todos as figuras normativas brasileiras e internacionais, bem como, a atuação do gestor público do Brasil para a efetivação destas legislações se mostra imprescindível na atual conjuntura contemporânea, porquanto, segundo as estatísticas do Ministério da Justiça e Segurança Pública no compilado do "Refúgio em Números" em sua $4^{\mathrm{a}}$ edição, só no ano de 2018 foram feitas 80.057 solicitações de reconhecimento da condição de refugiado (BRASIL, 2019), o que demonstra um aumento substancial, visto que, na $3^{\mathrm{a}}$ edição foi contatado que no ano de 2017 houveram 33.866 pleitos (BRASIL, 2018), enquanto que na $2^{\mathrm{a}}$ edição deste mesmo estudo relativo ao ano de 2016 foi constatado que houveram 10.308 pedidos (BRASIL, 2017), contudo, o grande aumento de pedidos remonta uma análise da $1^{\mathrm{a}}$ edição destas pesquisas, que apontam para o seguinte levantamento: no ano de 2010 houveram apenas 966 pedidos, em 2011 triplicou-se e chegou ao número de 3.220 pleitos, enquanto que em 2012 alcançou 4.022, em 2013 houve um extraordinário aumento para 17.631 requerimentos, em 2014 foram 28.385 e em 2015 se alcançou a marca de 28.670 pedidos (BRASIL, 2016), logo, a presença dos refugiados é uma realidade que não pode ser ignorada. 
O último levantamento disponibilizado pelo Poder Executivo Federal - na aludida $4^{\mathrm{a}}$ edição do Refúgio em Números - foi o de que, até dezembro de 2018 na República Federativa do Brasil há um acumulado de 11.231 pessoas reconhecidas como refugiadas, e um total de 161.057 solicitações em trâmite, totalizando assim 172.288 pessoas buscando uma nova vida neste Estado. E tendo em vista que o último censo do IBGE calculado até $1^{\circ}$ de julho de 2019 teve uma estimativa populacional de 210.147.125 habitantes (IBGE, 2019), mostra-se crível asseverar que 0,081984\% dos habitadores brasileiros são refugiados e, evidentemente, merecem a devida tutela jurídica.

Especificamente em relação ao meio ambiente laborativo, o Ministério do Trabalho brasileiro noticiou que, do ano de 2010 até o ano de 2019 foram localizados 723 estrangeiros em condições análogas a de escravo (BRASIL, 2019b), que comparados aos 172.288 refugiados, corresponde à $0,41964 \%$ de pessoas inseridas em um meio ambiente do trabalho desequilibrado e prejudicial aos seus Direitos da personalidade.

Além disso, o Portal do Ministério do Trabalho sobre a lista de "empregadores que submeteram empregados a condição análoga a de escravo" informa que até o mês de dezembro do ano de 2019 houve a inserção de 146 empresas neste rol (BRASIL, 2019c), entretanto, tal banco de dados é omisso em relação ao número de refugiados que foram resgatados destes ambientes indignos ao trabalho, ou seja, tal omissão impede uma análise pormenorizada, mas aponta para a existência de alguma fiscalização, tanto é que, no denominado "Painel de Informações e Estatística da Inspeção do Trabalho no Brasil" foi relatado que do ano de 1995 ao ano de 2019 foram resgatados ao todo 54.285 trabalhadores (BRASIL, 2019).

Não obstante, segundo o Relatório Anual do Observatório de Migrações Internacionais (OBMigra), no ano de 2019 o Brasil emitiu 36.384 Carteiras de Trabalho e Previdência Social (CTPS) para solicitantes de Refúgio (CAVALCANTI; OLIVEIRA; MACÊDO; PEREIRA, 2019, p. 02), este mesmo relatório aponta que, do ano de 2010 a 2018 foram emitidas 76.878 unidades deste documento 
Da Personalidade Ao Trabalho: Um Estudo Sobre 0 Ambiente Laborativo Dos...

(CAVALCANTI; OLIVEIRA; MACÊDO; PEREIRA, 2019, p. 07) e que em geral os contratos de trabalho possuem as seguintes características:

\begin{abstract}
De 2011 a 2017 os solicitantes de refúgio e refugiados estiveram inseridos nos grupos ocupacionais de produção de bens e serviços industriais e nos serviços e comércio. As principais atividades foram a indústria, demais serviços e comércio. Em 2017, a indústria respondia por 38,8\% dos postos de trabalho, seguida por serviços em geral $(29,3 \%)$ e comércio e reparação (20,3\%). Entre 2011 e 2017, mais de $90 \%$ tinham jornadas de trabalho de 44 horas ou mais por semana, sendo que o pico foi atingido em 2013, com 97,9\%. 1,5 salário mínimo, com variação real entre 2011 e 2017 de 9,1\%. (CAVALCANTI; OLIVEIRA; MACÊDO; PEREIRA, 2019, p. 07)
\end{abstract}

Embora tenha tido expressivas emissões de CTPS, este número não corresponde ao número de vagas formais de emprego ocupadas por migrantes nos anos de 2011 (36.364), 2012 (46.066), 2013 (73.717), 2014 (100.849), 2015 (94.870), 2016 (70.335), 2017 (71.814) e 2018 (72.081), o que aponta para o fato de que os refugiados são a minoria em relação aos demais trabalhadores estrangeiros em solo brasileiro. (CAVALCANTI; OLIVEIRA; MACÊDO; PEREIRA, 2019, p. 05)

Tais acontecimentos demonstram a necessária correlação que deve haver entre às normas internacionais e a legislação interna (Poder Legislativo), e, consequentemente, a aplicação de políticas públicas e de fiscalização do Poder Executivo, sem prejuízo da atuação do Poder Judiciário, e nesta conjunção de poderes alcançar a efetividade do texto legal. (NEVES, 1994, p. 46)

Não se pode deixar de destacar as parcerias feitas pelo Serviço Nacional de Aprendizagem Industrial (SENAI), o Serviço Social da Indústria (SESI), o Serviço Nacional de Aprendizagem Comercial (SENAC) e o Serviço Social do Comércio (SESC), com a Caritas (organização humanitária da Igreja Católica), que promovem encaminhamentos e capacitações com estes órgãos, facilitando a inclusão no mercado de trabalho, pelos refugiados (ACNUR, 2020). 
E da análise dos dados supracitados é possível afirmar que há certa efetividade das normas no plano interno, ressaltando-se ainda, que a efetividade é gradual, e in casu, estes dados, embora, não definitivos sobre o tema, permitem o entendimento de que a norma brasileira possui sim certo patamar de efetividade e como tal, não destoa das normas internacionais, no entanto, ainda são insuficientes as políticas públicas de concretização das mesmas.

\section{CONCLUSÃo}

Diante de todo o exposto, é possível concluir que há um grande conjunto de normas internacionais que visam resguardar os refugiados, que podem ser considerados como o grupo de pessoas que se desloca de um local ou país para outro por motivos de raça, religião, nacionalidade, grupo social ou opinião política, e atualmente, por desastre ambiental, que causam penúria e impossibilidade de permanência em seu território de origem.

Por terem se deslocado para outro Estado em um contexto de grande dificuldade social e jurídica, os refugiados são considerados como vulneráveis do ponto de vista dos Direitos da personalidade e do meio ambiente do trabalho, uma vez que, a aludida dificuldade acaba forçando-os a aceitar condições precárias de trabalho subjugando assim os seus Direitos personalíssimos, tais como, a integridade física, saúde, honra, intimidade, privacidade, enfim, as mais variadas facetas de sua individualidade.

$\mathrm{O}$ fato de muitos empregadores detentores do capital visarem maiores lucros mediante a redução dos valores e das garantias próprias do meio ambiente do trabalho demonstram que a precarização acaba sendo vantajosa, principalmente, quando empregada em desfavor dos refugiados que necessitam imediatamente de uma fonte mínima de renda, logo, para melhorar a sua 
Da Personalidade Ao Trabalho: Um Estudo Sobre 0 Ambiente Laborativo Dos...

competitividade, aqueles acabam ajustando sua conduta ao denominado dumping social.

E após a análise das previsões constitucionais e das normas infraconstitucionais brasileiras de maior destaque sobre os Direitos da personalidade, sobre o meio ambiente, inclusive do trabalho e sobre refugiados, além da análise das principais normas administrativas pertinentes às políticas públicas sobre o tema, e de julgados de Cortes superiores, foi possível constatar que há um conjunto normativo relevante que formalmente atende ao escopo da igualdade material que pode, em tese, salvaguardar os refugiados, no entanto, nem sempre são efetivas.

Portanto, mostra-se plausível asseverar que sim, o ordenamento jurídico brasileiro converge com as normas internacionais sobre os Direitos da personalidade e o meio ambiente do trabalho em relação aos refugiados, há normas criadas pelo Poder Legislativo com tal desiderato, porém, resta o alerta para a atuação do Poder Executivo Federal que poderia aplicar mais recursos e integrar as políticas públicas em vários setores desconcentrados (Ministérios e suas Secretarias) ou descentralizados (Administração Pública indireta) gerando maior aplicabilidade de tais normas e efetivas políticas públicas, por fim, também se observou que o Poder Judiciário em nível hierárquico superior ainda possui poucos julgados, mas que evidencia, que pode aplicar as mencionadas normas em caso de inércia dos demais poderes.

Por derradeiro, os dados estatísticos levantados permitem a conclusão de que as citadas normas internas do Estado brasileiro possuem certo grau de efetividade, reforçando assim a necessidade de maior aplicabilidade destas mesmas figuras normativas, como é o caso, a título de exemplo, da resolução 03/2016, que deveria reconhecer diplomas estrangeiros e que poderia alavancar a inclusão de refugiados ao meio ambiente de trabalho, no entanto, tem se mostrado burocrática e com pouca efetividade. 
Data de Submissão: 01/11/2019

Data de Aprovação: 18/12/2019

Processo de Avaliação: double blind peer review

Editor Geral: Jailton Macena de Araújo

Editor de Área: Jailton Macena de Araújo

Assistente Editorial: Jaime Waine Rodrigues Mangueira

\section{REFERÊNCIAS}

AKAOUI, Fernando Reverendo Vidal. O papel das empresas na implantação da política nacional do meio ambiente. In. SAMPAIO, Rômulo S. R; LEAL, Guilherme, J. S; REIS, Antonio Augusto. Tópicos de direito ambiental: 30 anos da política nacional do meio ambiente. Rio de Janeiro: Lumen Juris, 2011.

ALMEDIA-DINIZ, Arthur J. Novos paradigmas em Direito Internacional Público. Porto Alegre: Sergio Antonio Fabris Editor, 1995.

ANTUNES, Ricardo. O Privilégio da Servidão. O novo proletariado de serviços na era digital.São Paulo: Boitempo, 2018.

BARRICHELLO, Stefania Eugenia; ARAÚJO, Luiz Ernani Bonesso de. Aspectos históricos da evolução e do reconhecimento internacional do status de refugiado. In. Universitas Relações Internacionais, Brasília, v. 12, n. 2, p. 63-76, jul./dez. 2014.

BRASIL. ACNUR. Alto Comissariado das Nações Unidas para os Refugiados. Refugiados. Proteção e Assistência em São Paulo. Disponível em: https://www.acnur.org/portugues/wpcontent/uploads/2018/02/Refugiados Prote\%C3\%A7\%C3\%A30-eassist\%C3\%AAncia-em-S\%C3\%A30-Paulo.pdf , acesso em 09/02/20.

BRASIL. INSTITUTO BRASILEIRO DE GEOGRAFIA E ESTATISTICA - IBGE. Disponível em: < https://www.ibge.gov.br/estatisticas/sociais/populacao/9103estimativas-de-populacao.html? $=\& \mathrm{t}=$ resultados $>$, acesso em dezembro de 2019. 
Da Personalidade Ao Trabalho: Um Estudo Sobre 0 Ambiente Laborativo Dos...

BRASIL. MINISTÉRIO DA JUSTIÇA. Refúgio em Números. $1^{\mathrm{a}}$ edição. Disponível em: < https://www.justica.gov.br/seusdireitos/refugio/anexos/10-edicao-sistema de refugio brasileiro refugio em numeros - 05 05 2016.pdf $>$, acesso em dezembro de 2019.

BRASIL. MINISTÉRIO DA JUSTIÇA. Refúgio em Números. $2^{\text {a }}$ edição. Disponível em: < https://www.justica.gov.br/seusdireitos/refugio/anexos/2deg-edicao-refugio-em-numeros-20102016-v-5-0-final.pdf $>$, acesso em dezembro de 2019.

BRASIL. MINISTÉRIO DA JUSTIÇA. Refúgio em Números. $3^{\text {a }}$ edição. Disponível em: < https://www.justica.gov.br/seusdireitos/refugio/anexos/refasgio-em-nasmeros 1104.pdf $>$, acesso em dezembro de 2019.

BRASIL. MINISTÉRIO DA JUSTIÇA. Refúgio em Números. $4^{\mathrm{a}}$ edição. Disponível em: < https://www.acnur.org/portugues/wpcontent/uploads/2019/07/Refugio-emnu\%CC\%81meros versa\%CC\%830-23-de-julho-002.pdf $>$, acesso em dezembro de 2019.

BRASIL. MINISTÉRIO DO TRABALHO. Disponível em: < http://trabalho.gov.br/noticias/7122-inspecao-do-trabalho-resgata723-estrangeiros-submetidos-a-condicoes-analogas-as-de-escravo> acesso em dezembro de 2019.

BRASIL. MINISTÉRIO DO TRABALHO. Disponível em: < http://trabalho.gov.br/images/Documentos/SIT/CADASTRO DE EMPREGADORES.pdf >, acesso em dezembro de 2019.

BRASIL. MINISTÉRIO DO TRABALHO. Disponível em: < https://sit.trabalho.gov.br/radar/>, acesso em dezembro de 2019.

BRASIL. STF. Ext 1008, Relator(a): Min. GILMAR MENDES, Relator(a) p/ Acórdão: Min. SEPÚLVEDA PERTENCE, Tribunal Pleno, julgado em 21/03/2007, DJe-082 DIVULG 16-08-2007 PUBLIC 17-08-2007 DJ 17-08-2007 PP-00024 EMENT VOL-0228502 PP-00216.

BRASIL. STF. Ext 1170, Relator(a): Min. ELLEN GRACIE, Tribunal Pleno, julgado em 18/03/2010, DJe-071 DIVULG 22-04-2010 PUBLIC 23-04-2010 EMENT VOL-02398-01 PP-00001 RTJ VOL00214-01 PP-00011 LEXSTF v. 32, n. 377, 2010, p. 280-286 RT v. 100, n. 904, 2011, p. 512-515.

BRASIL. STJ. HC 333.902/DF, Rel. Ministro HUMBERTO MARTINS, PRIMEIRA SEÇÃO, julgado em 14/10/2015, DJe 22/10/2015. 
BRASIL. STJ. REsp 1475580/RJ, Rel. Ministro LUIS FELIPE SALOMÃO, QUARTA TURMA, julgado em 04/05/2017, DJe 19/05/2017.

BRASIL. STJ. REsp 1487032/SP, Rel. Ministro HUMBERTO MARTINS, SEGUNDA TURMA, julgado em 03/o3/2015, DJe 09/03/2015.

BRASIL. TST. Numeração Única: AIRR - 58-91.2011.5.04.0030. Relator Desembargador. Convocado: Paulo Américo Maia de

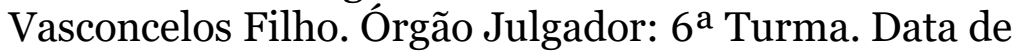
julgamento: 01/10/2014.

CANÇADO TRINDADE, Antônio Augusto. Tratado de Direito Internacional dos Direitos Humanos. Porto Alegre: Fabris, 1997.

CARDOSO FILHO, Gamaliel F; TOMAZ, Rodrigo G. In. O assédio moral no trabalho e sua desumanizante violação dos direitos da personalidade moral. In. BARBATO, Maria Rosaria; SILVA, Luciana Aboim M. G. da; CATÃO, Marconi do o. Direito do Trabalho II. $1^{\circ}$ edição. Florianópolis: CONPEDI, 2014.

CAVALCANTI, L; OLIVEIRA, T; MACÊDO, M; PEREDA, L. Resumo Executivo. Imigração e Refúgio no Brasil. A inserção do imigrante, solicitante de refúgio e refugiado no mercado de trabalho formal. Observatório das Migrações Internacionais; Ministério da Justiça e Segurança Pública/Conselho Nacional de Imigração e Cordenação Geral de Imigração Laboral. Brasília,DF: OBMigra, 2019.

CECATO, Maria Aurea Baroni; OLIVEIRA, Armando Albuquerque de. Direitos Sociais: do Estado Liberal ao Estado Social. In. Revista PRIM@ FACIE. João Pessoa: PPGCJ, v. 15, n. 29, 2016. Disponível em: $<$

https://periodicos.ufpb.br/index.php/primafacie/article/view/33120 L17165>, acesso em dezembro de 2019.

DAVIES, Ana C. I. Políticas públicas: a forma ideal de concretização da dimensão objetiva dos direitos fundamentais. In. SIQUEIRA, Dirceu P; ANSELMO, José R. Estudos sobre os direitos fundamentais e inclusão social: da falta de efetividade à necessária judicialização, um enfoque voltado à sociedade contemporânea. Birigui: Boreal, 2010.

DEL'OLMO, Florisbal de Souza. Curso de direito internacional público. $1^{\text {a }}$ edição. Rio de Janeiro: Forense, 2006.

DELGADO, Mauricio Godinho. Curso de Direito do Trabalho. 9 Ed. São Paulo: LTr, 2010. 
Da Personalidade Ao Trabalho: Um Estudo Sobre 0 Ambiente Laborativo Dos...

FERREIRA, Aurélio Buarque de Holanda. Dicionário Aurélio da Língua Portuguesa. 5 Ed. Curitiba: Positivo, 2010.

FERREIRA, Rafael Almeida Jatahy. Tutela jurídica do meio ambiente do trabalho. In. ASENSI, Felipe Dutra; PINHEIRO, Roseni. Direito Sanitário. Rio de Janeiro: Elsevier, 2012.

FERRER, Walkiria Martinez Heinrich; ALVES, Giovanni.

Flexibilização Trabalhista e o Empresariado Brasileiro: alguns apontamentos. In. Revista PRIM@ FACIE. João Pessoa: PPGCJ, v. 17, n. 35, 2018. Disponível em: <

https://periodicos.ufpb.br/index.php/primafacie/article/view/3947 $\underline{\mathrm{o} / 20512}>$, acesso em dezembro de 2019.

FIORILLO, Celso Antonio Pacheco. Curso de direito ambiental brasileiro. 11 Ed. São Paulo: Saraiva, 2010.

FIUZA, César. Direito Civil Curso Completo. 11 Ed. Belo Horizonte: Del Rey, 2008.

GARBACCIO, Grace Ladeira; DENNY, Danielle Mendes Thame; JULIÃO, Rodrigo de Farias. O Trabalho na Pós-Modernidade. In. Revista PRIM@ FACIE. João Pessoa: PPGCJ, v. 16, n. 31, 2017. Disponível em: < https://periodicos.ufpb.br/index.php/primafacie/article/view/3343 9/17598 >, acesso em dezembro de 2019.

GOMES, Luiz Flávio; MAZZUOLI, Valério de Oliveira. Comentários à Convenção Americana sobre Direitos Humanos: Pacto de San José da Costa Rica. 4 Ed. Revista dos Tribunais, 2013.

GROKSKREUTZ, Hugo Rogério. O direito à saúde e a responsabilidade estatal no sistema regional americano de Direitos humanos. In. ASENSI, Felipe; PINHEIRO, Roseni; ARÉVALO, Paula Lucia. Direito à saúde: enfoques interdisciplinares. Curitiba: Juruá, 2013.

HARARI, Yuval Noah. Sapiens: uma breve história da humanidade. 28 Ed. Porto Alegre: L\&PM, 2017.

HUBERMAN, Leo. História da riqueza do homem: do feudalismo ao século XXI. Tradução: Waltensir Dutra. 22 Ed. Rio de Janeiro: LTC, 2017.

HUNT, E.K; SHERMAN, Howard J. História do pensamento econômico. Tradução: Jaime Larry Benchimol. 25 Ed. Petrópolis: Vozes, 2010.

INSTITUTO HUMANITAS UNISINOS. Disponível em: http://www.ihu.unisinos.br/78-noticias/585919-em-comunicado-a- 
diplomatas-governo-bolsonaro-confirma-saida-de-pacto-demigracao-da-onu. Acesso em abril de 2019.

LEITE, Carlos Henrique Bezerra. Direitos humanos. 2 Ed. Rio de Janeiro: Lumen Juris, 2011.

\section{LIGA DAS NAÇÕES. Convenção sobre o Estatuto}

\section{Internacional dos Refugiados de 1933.}

https://dl.wdl.org/11580/service/11580.pdf $>$. Acesso em abril de 2019.

LIMA, João Brígido Bezerra. Et ali. Refúgio no Brasil: caracterização dos perfis sóciodemográficos dos refugiados (1998-2014). Brasília. Ipea, 2017.

LIPOVETSKY, Gilles. A felicidade paradoxal: ensaio sobre a sociedade de hiperconsumo. Tradução: Maria Lucia Machado. São Paulo: Companhia das Letras, 2007.

LORENZETTI, Ricardo Luis. Teoria geral do direito ambiental. Tradução de Fábio Costa Morosini e Fernanda Nunes Barbosa. São Paulo: Revista dos Tribunais, 2010.

MAGALHÃES, Humberto Piragibe; MALTA, Christovão Pirabibe Tostes. Dicionário Jurídico. 8 Ed. Rio de Janeiro: Destaque, 1997.

MARX, Karl. O capital. Tradução e condensação: Gabriel Deville. Bauru: EDIPRO, 1998.

MAZZUOLI, Valério de Oliveira. Curso de direito internacional público. 9 Ed. São Paulo: Revista dos Tribunais, 2015.

MAZZUOLI, Valério de Oliveira. Os sistemas regionais de proteção dos direitos humanos: uma análise comparativa dos sistemas interamericano, europeu e africano. São Paulo: Revista dos Tribunais, 2011.

MEDINA, José M. G; ARAÚJO, Fábio C. de. Código Civil Comentado. São Paulo: Revista dos Tribunais, 2014.

MILARÉ, Édis. Direito do ambiente. 10 Ed. São Paulo: Revista dos Tribunais, 2015.

MONTENEGRO, Aline Ferreira; FERRAZ, Miriam Olivia Knopik; VILLATORE, Marco Antônio César. Os Direitos Sociais e os Obstáculos à Efetivação do Princípio da Proteção ao Hipossuficiente no Acesso à Jurisdição Trabalhista após a Publicação da Lei $\mathrm{n}^{\circ}$ 13.467/2017. In. Revista PRIM@ FACIE. João Pessoa: PPGCJ, v. 18, n. 37, 2019. Disponível em: < https://periodicos.ufpb.br/index.php/primafacie/article/view/40716 $\lcm{22589}>$, acesso em dezembro de 2019. 
Da Personalidade Ao Trabalho: Um Estudo Sobre 0 Ambiente Laborativo Dos...

MORAES, Maria C. B. de. Ampliando os Direitos da

Personalidade. Revista de Saúde Pública, v. 41, n. 5, 2007. In. http://www.academia.edu/9689598/Ampliando os direitos da pe rsonalidade. Acesso em abril de 2019.

NASCIMENTO, Amauri M. Iniciação ao Direito do Trabalho.

São Paulo: LTr, 2005.

NASCIMENTO, Amauri M.; NASCIMENTO, Sônia Mascaro. Curso de Direito do Trabalho. 29 Ed. São Paulo: Saraiva, 2015.

NERY JUNIOR, Nelson; NERY, Rosa Maria de A. Código Civil Comentado. 11 Ed. São Paulo: Revista dos Tribunais, 2014.

NEVES, Marcelo. Constitucionalização simbólica. $1^{\mathrm{a}}$ edição. São Paulo: Acadêmica, 1994.

ORGANIZAÇÃO DAS NAÇÕES UNIDAS (ONU). Carta das Nações

Unidas. In. < https://nacoesunidas.org/wpcontent/uploads/2017/11/A-Carta-das-Na\%C3\%A7\%C3\%B5es-

Unidas.pdf $>$, acesso em 25 de março de 2019.

ORGANIZAÇÃO DAS NAÇÕES UNIDAS (ONU). Convenção Relativa aos Direitos dos Refugiados. In. <

https://www.acnur.org/fileadmin/Documentos/portugues/BDL/Con vencao relativa ao Estatuto dos Refugiados.pdf $>$, acesso em março de 2019.

ORGANIZAÇÃO DAS NAÇÕES UNIDAS (ONU). Declaração de Nova Iorque para Imigrantes e Refugiados. In. < https://www.globalcrrf.org/wpcontent/uploads/2018/07/Declara\%C3\%A7\%C3\%A3o-de-NovaIorque-para-Refugiados-e-Migrantes.pdf. > . Acesso em abril de 2019.

ORGANIZAÇÃO DAS NAÇÕES UNIDAS (ONU). Declaração e Programa de Ação de Viena. In. < https://www.ohchr.org/Documents/ProfessionalInterest/vienna.pdf $>$, acesso em 25 de março de 2019.

ORGANIZAÇÃO DAS NAÇÕES UNIDAS (ONU). Declaração Universal de Direitos Humanos. In. < https://nacoesunidas.org/wp-content/uploads/2018/10/DUDH.pdf $>$, acesso em abril de 2019.

ORGANIZAÇÃO DAS NAÇÕES UNIDAS (ONU). Estatuto da ACNUR. In. <https://www.acnur.org/fileadmin/Documentos/portugues/BD Leg al/Instrumentos Internacionais/Estatuto ACNUR.pdf?file=fileadmi n/Documentos/portugues/BD Legal/Instrumentos Internacionais/ Estatuto ACNUR >. Acesso em abril de 2019. 
ORGANIZAÇÃO DAS NAÇÕES UNIDAS (ONU). Organização Internacional para a as migrações (OIM). In. < https://nacoesunidas.org/agencia/oim/ > . Acesso em abril de 2019.

ORGANIZAÇÃO DAS NAÇÕES UNIDAS (ONU). Pacto global para a migração. In. < https://nacoesunidas.org/mais-de-160-paisesadotam-pacto-global-para-a-migracao/ > . Acesso em abril de 2019.

ORGANIZAÇÃO DAS NAÇÕES UNIDAS (ONU). Proclamação de Teerã. In. <

http://www.direitoshumanos.usp.br/index.php/Confer\%C3\%AAncia s-de-C\%C3\%BApula-das-Na\%C3\%A7\%C3\%B5es-Unidas-sobreDireitos-Humanos/proclamacao-de-teera.html > acesso em 25 de março de 2019.

ORGANIZAÇÃO DAS NAÇÕES UNIDAS (ONU). Recomendação 205 da OIT. In. <

https://www.ilo.org/dyn/normlex/es/f?p=NORMLEXPUB:12100:0:: NO::P12100 INSTRUMENT ID:3330503 >, acesso em abril de 2019.

ORGANIZAÇÃO DOS ESTADOS AMERICANOS (OEA). Carta de Organização dos Estados Americanos. Disponível em: https://www2.camara.leg.br/legin/fed/decret/1950-1959/decreto30544-14-fevereiro-1952-340000-publicacaooriginal-1-pe.html $>$. Acesso em abril de 2019.

ORGANIZAÇÃO DOS ESTADOS AMERICANOS (OEA). Carta Internacional Americana de Garantias Sociais dos Trabalhadores. <

http://www.ordenjuridico.gob.mx/TratInt/Derechos\%20Humanos/ OTROS\%2001.pdf. > Acesso em abril de 2019.

ORGANIZAÇÃO DOS ESTADOS AMERICANOS (OEA). Comisión Americana De Derechos Humanos. Movilidad humana estándares interamericanos. Disponível em: < http://www.oas.org/es/cidh/informes/pdfs/MovilidadHumana.pdf $>$, acesso em dezembro de 2019.

ORGANIZAÇÃO DOS ESTADOS AMERICANOS (OEA). Convenção Americana de Direitos Humanos. Disponível em: http://www.planalto.gov.br/ccivil 03/decreto/Do678.htm. Acesso em abril de 2019.

ORGANIZAÇÃO DOS ESTADOS AMERICANOS (OEA). Corte Interamericana De Direitos Humanos. Caso n ${ }^{\circ}$. 12.474 - Familia Pacheco Tineo vs. Estado Plurinacional de Bolivia.

Disponível em: < http://www.corteidh.or.cr/tablas/fichas/pachecotineo.pdf $>$, acesso em dezembro de 2019. 
Da Personalidade Ao Trabalho: Um Estudo Sobre 0 Ambiente Laborativo Dos...

ORGANIZAÇÃO DOS ESTADOS AMERICANOS (OEA).

Declaração de Cartagena. In.

https://www.acnur.org/fileadmin/Documentos/portugues/BD Lega l/Instrumentos Internacionais/Declaracao de Cartagena.pdf.

Acesso em abril de 2019.

ORGANIZAÇÃO DOS ESTADOS AMERICANOS (OEA).

Declaração de San José sobre refugiados e pessoas

deslocadas. Disponível em: http://pfdc.pgr.mpf.mp.br/atuacao-e-

conteudos-de-apoio/legislacao/asilos-refugiados-e-

apatridas/declaracao-de-sao-jose-sobre-refugiados-e-pessoas-

deslocadas-1994. Acesso em abril de 2019.

ORGANIZAÇÃO DOS ESTADOS AMERICANOS (OEA).

Declaração do Brasil de 2014. In. <

https://www.acnur.org/fileadmin/Documentos/BDL/2014/9866.pdf

$>$. Acesso em abril de 2019.

ORGANIZAÇÃO DOS ESTADOS AMERICANOS (OEA).

Declaração e plano de ação do México de 2004. In. < https://www.acnur.org/fileadmin/Documentos/portugues/BD Lega 1/Instrumentos Internacionais/Declaracao e Plano de Acao do Mexico.pdf $>$. Acesso em abril de 2019.

ORGANIZAÇÃO DOS ESTADOS AMERICANOS (OEA). Princípios e critérios para a proteção e assistência aos refugiados, repatriados e deslocados centro americanos na América Latina de 1989. In.

$<$ https://www.acnur.org/fileadmin/Documentos/BDL/2001/0179.p df?view=1>. Acesso em abril de 2019.

ORGANIZAÇÃO DOS ESTADOS AMERICANOS (OEA). Protocolo de São Salvador. Disponível em:

http://www.planalto.gov.br/ccivil 03/decreto/D3321.htm. Acesso em abril de 2019.

PORTELA, Paulo Henrique Gonçalves. Direito internacional público e privado. $3^{\mathrm{a}}$ Ed. Salvador: Juspodvm, 2011, p. 311.

RAMINA, Larissa; ANDRADE, Varelia Pereira de. Refúgio e dignidade da pessoa humana: breves considerações. In. ANNONI, Danielle. Direito internacional dos refugiados e o Brasil.

Curitiba: Gedai/UFPR, 2018.

RIBEIRO, Guilherme. O constitucionalismo e a necessária pluralidade do sujeito constitucional: reflexões teóricas para compreensão da igualdade material. In. SIQUEIRA, Dirceu Pereira; ANSELMO, José R. Estudos sobre os direitos fundamentais e inclusão social: da falta de efetividade à necessária judicialização, um enfoque voltado à sociedade contemporânea. Birigui: Boreal, 2010. 
SAADEH, Cyro; EGUCHI, Mônica M.. Convenção relativa ao estatuto dos refugiados: protocolo sobre o estatuto dos refugiados. São Paulo, 1998. In. <

http://www.pge.sp.gov.br/centrodeestudos/bibliotecavirtual/direito s/tratado12.htm $>$. Acesso em abril de 2019.

SÉGUIN, Elida. Educação ambiental e meio ambiente do trabalho. In. DANTAS, Marcelo B; SÉGUIN, Elida; AHMED, Flávio. O Direito ambiental na atualidade: estudos em homenagem a Guilherme José Purvin de Figueiredo. Rio de Janeiro: Lumen Juris, 2010.

SILVA, Leda M. M. da. Os imigrantes no brasil, sua vulnerabilidade e o princípio da igualdade. In. Revista Brasileira de Políticas Públicas (Online), Brasília, v. 7, $\mathrm{n}^{0}$ 2, 2017 p. 384-403.

SILVA, Leda M. M. da; LIMA, Sarah Somensi. Imigração Haitiana no Brasil: os Motivos da Onda Migratória, as Propostas para a Inclusão dos Imigrantes e a sua Proteção à Dignidade Humana. In. Direito, Estado e Sociedade, n. 48, p. 167 a 195, jan/jun 2016.

SILVA, Leda M. M. da; NOVAES, Milaine A. Dumping social e dignidade do trabalhador no meio ambiente de trabalho: propostas para a redução da precarização. Revista eletrônica do Tribunal Regional do Trabalho da 9 ${ }^{\mathbf{a}}$ Região, Curitiba, PR, v. 4, n. 43, p. 22-39, ago. 2015.

SIQUEIRA, Dirceu Pereira Et ali. Os direitos da personalidade em face da dicotomia direito público - direito privado. In. Revista de Direito Brasileira. São Paulo, SP, v. 19, n. 8, p. 208-220. Jan./Abr. 2018.

\section{SIQUEIRA, Dirceu Pereira. A dimensão cultura do Direito} fundamental à alimentação. $1^{\mathrm{a}}$ edição. Birigui: Boreal, 2013.

SIQUEIRA, Dirceu Pereira; MARTA, Taís N. O direito fundamental à saúde para pacientes especiais na odontologia: uma análise sobre o prisma de uma efetiva inclusão social. in. SIQUEIRA, Dirceu P; PICCIRILLO, Miguel B. Inclusão social e direitos fundamentais. Birigui: Boreal, 2009.

THEMUDO, Tiago Seixas; NOGUEIRA, Mônica de Sá Pinto Nogueira. O exercício solidário e social da empresa ante as Relações de trabalho no Brasil. In. Revista Jurídica Cesumar - Mestrado, v. 19, n. 2, p. 403-428, maio/agosto 2019. Disponível em: < https://periodicos.unicesumar.edu.br/index.php/revjuridica/article/ view $/ 7140 / 3530>$, acesso em dezembro de 2019.

VALENTE, Nara Luiza; FOGAÇA, Vitor Hugo Bueno; SILVA, Silmara Carneiro e. A Reforma Trabalhista Brasileira E Retrocessos Na Garantia De Direitos Fundamentais Do Trabalhador. In. Revista Prim@ Facie. João Pessoa: PPGCJ, v. 17, n. 35, 2018. Disponível 
Da Personalidade Ao Trabalho: Um Estudo Sobre 0 Ambiente Laborativo Dos...

em:

$<$ https://periodicos.ufpb.br/index.php/primafacie/article/view/388 $\underline{14 / 20918}>$, acesso em dezembro de 2019.

VILA NOVA, Sebastião. Introdução à sociologia. 5 Ed. São Paulo: Atlas, 2000. 


\title{
From Personality To Work: A Study On The Labor Environment Of Refugees In Brazil And The Effectiveness Of The Rules
}

\author{
Gustavo Noronha de Ávila
}

Leda Maria Messias da Silva

Hugo Rogério Grokskreutz

\begin{abstract}
Personality rights protects the whole integrity of human person. These are general values applicable to all juridical relationships, including the work environment, which is the space where the person exercises its daily labor activities. Therefore, their personal values must be protected also in this context. Beacause of persecution arising from race, religion, nationality, group relations and political opinion, people migrate to other states and are considered refugees, being protected by the american system of human rights and local legislation. So that, in fact, their personality rights are respected in the work environment, it is necessary to have effectiveness of the rules and, therefore, may promote public politics of inclusion. It was used the deductive methodological approach, with use of the bibliographic and documentary reasearch procedure. It was concluded that the brazilian legislation are formally adjusted to the alluded international law and that, internally, they are relatively effective.
\end{abstract}

Keywords: Refugees. Work environment. Rights of the personality. Effectiveness of the Rules. Inclusive Public Politics.

DOI: https://doi.org/10.22478/ufpb.1678-2593.2020v19n40.48763

Conteúdo sob licença Creative Commons: Attribuition-NonCommercial-NoDerivative 4.o International (CC BY-NC-ND 4.0) 